\title{
PENGARUH GAYA KEPEMIMPINAN SITUASIONAL DAN BUDAYA ORGANISASI TERHADAP KEPUASAN KERJA PADA KANTOR BADAN KEUANGAN DAERAH PROVINSI SUMATRA BARAT
}

\author{
Muslina Rafika Putri, Henryanto Abaharis \\ Sekolah Tinggi Ilmu Ekonomi KBP \\ Muslinaravika@gmail.com
}

\begin{abstract}
Situational leadership style is a style or way of leadership that is shown by a leader to guide, carry out, direct, encourage subordinates to achieve goals and optimally utilize all their abilities by combining the existing situation with regard to the behavior of leaders and subordinates. Organizational culture is a habit that occurs in organizational hierarchies that represent behavioral norms followed by members of the organization. Organizational culture is to spread belief systems and values that develop within an organization and direct the behavior of its members. Job satisfaction reflects a person's feelings towards his work, seen in the positive attitude of employees towards work and all that is encountered in their work environment. This study aims to determine the effect of situational leadership style and organizational culture on the Job Satisfaction of the Regional Finance Office of West Sumatra Province. Variable Situational Leadership Style has a significant effect on job satisfaction by 48.0\%. Organizational Culture Variables have a significant effect on Job Satisfaction by $17.7 \%$. Based on the analysis, it is known that the determination coefficient value of Adjusted $R$ Square is 0.488 , which means $48.8 \%$ of the variables of job satisfaction are influenced by the variables of situational leadership style and organizational culture.
\end{abstract}

Keywords: situational leadership, organizational culture, job satisfaction

\section{PENDAHULUAN}

Kepuasan kerja merupakan suatu yang sangat sulit diukur yang bersifat subjektif karena setiap orang selalu mempunyai keinginan-keinginan yang ingin dipenuhi namun setelah terpenuhi muncul lagi keinginan setiap pegawai mempunyai kriteria sendiri yang menyenangkan bahwa dirinya telah puas. Menurut davis dalam penelitian(Hamid \& Mukzam, 2008) seperangkat perasaan pegawai tentang menyenangkan atau tidak nya pekerjaan mereka. Kepuasan kerja bisa dilihat atau dikatakan puas dalam bekerja jika pendapatan yang diperoleh telah dapat mencukupi kebutuhan pekerja tersebut, dan dalam purusahaan tersebut pegawai merasakan nyaman dalam bekerja dan tidak mempunyai kekhawatiran lain seperti kurang cukup gaji yang diterima, tidak adanya jaminan kesehatan/keselamatan kerja dan jaminan masa tua atau pension. Kepuasan kerja (job satisfaction) mengacu pada sikap individu secara umum terhadap pekerjaannya dapat juga dikatakan sebagai persepsi awal terhadap keberhasilan suatu pekerjaan.

Bagian Badan Keuangan Daerah Provinsi Sumatra Barat mempunyai sistem dan aturan yang mengatur tentang kepegawaian. Status dan proses penerimaan pegawai dibagi dalam dua bagian, yaitu pegawai yang telah diangkat menjadi Pegawai Negeri Sipil (PNS) dan pegawai yang belum diangkat sebagai PNS(honorer).Penilaian kepuasan kerja hanya bersifat obyektif, karena yang dinilai adalah hal-hal yang berhubungan dengan kepuasan kerja dan dianggap sebagai persyaratan wajib saja, misalnya beberapa kali kesalahan yang dibuatnya dalam melakukan tugasnya yang sama, serta kurangnya tanggapan terhadap masalah yang dihadapinya. Hal lain adalah berupa ketidak mampuan pegawai dalam menanggapi keluhan atas masalah yang sedang dihadapinya, kurang disiplin diri dalam hal absensi, dan masih banyak hal yang lainnya. 
Didalam Badan Keuangan Daerah terdapat struktur organisasi seperti halnya dengan perusahaan lain, maka dari itu diperlukan manajemen yang efektif dalam menjalankan fungsi organisasi tersebut, dengan mengelola Manajemen Sumber Daya Manusia-SDM secara efektif danefisien guna mencapai tujuan-tujuan organisasional.

Pemimpin yang melaksanakan kepemimpinannya secara efektif, dapat menggerakan orang/personil ke arah tujuan yang di cita-citakan, akan menjadi panutan dan teladan. Sebaliknya pemimpin yang keberadaannya hanya sebagai figur dan tidak memiliki pengaruh serta kemampuan kepemimpinannya, akan mengakibatkan kepuasan kerja organisasi menjadi lambat, karena ia tidak memiliki kecakapan untuk menghasilkan kepuasan kerja terbaik.

Berdasarkan uraian dan pemikiran tersebut di atas, penulis tertarik untuk mengadakan penelitian sebagai tugas akhir dengan mengambil judul:

"Pengaruh Gaya Kepemimpinan Situasional Dan Budaya Organisasi Terhadap Kepuasan Kerja Pada Kantor Badan Keuangan Daerah Provinsi Sumatra Barat".

Berdasarkan latar belakang yang telah penulis uraikan diatas maka permasalahan yang akan dirumuskan adalah :

1. Apakah gaya kepemimpinan situasional berpengaruh terhadap Kinerja Karyawan Badan Badan Keuangan Daerah Provinsi Sumatera Barat?

2. Apakah budaya organisasi berpengaruh terhadap kepuasan kerja karyawan Badan Keuangan Daerah Provinsi Sumatera Barat?

Adapun tujuan dalam penelitian ini adalah: Untuk mengetahui apakah gaya kepemimpinan berpengaruh positif dan signifikan terhadap kepuasan kerja karyawan Badan Keuangan Daerah Provinsi Sumatra barat.

1. Untuk mengetahui apakah budaya organisasi berpengaruh positif dan signifikan terhadap kepuasan kerja karyawan badan keuangan daerah Provinsi Sumatra Barat.

2. Untuk mengetahui apakah gaya kepemimpinan situasional dan budaya organisasi secara bersama-sama berpengaruh positif dan signifikan terhadap kepuasan kerja karyawan badan keuangan daerah Provinsi Sumatera Barat.

Penelitian ini diharapkan dapat memberikan manfaat bagi berbagai pihak, diantaranya :

1. Bagi pihak perusahaan

a. Kontribusi penelitian ini diharapkan dapat memberikan sumbangan pemikiran dalam pengaruh gaya kepemimpinan situasional dan budaya organisasi terrhadap kepuasan kerja pada kantor badan keuangan daerah Sumbar.

b. Sebagai bahan masukan bagi pimpinan HRD yaitu personalia agar melakukan peninjauan kembali terhadap gaya pemimpinan dan budaya organisasi dalam perusahaan.

c. Karyawan dapat mengetahui yang menjadi hak dan apa yang menjadi tanggung jawab sesuai dengan pekerjaannya.

2. Bagi peneliti

a. Penulis ini diharapkan dapat menjadi tambahan ilmu yang bermanfaat untuk dapat diterapkan di duniakerja.

b. Sebagai bahan masukan bagi penulis mengenai pengaruh gaya kepemimpinan situasional dan budaya organisasi terhadap kepuasan kerja karyawanguna menambah ilmu pengetahuan dan untuk mengetahui penerapan sebenarnya.

c. Untuk mengembangkan lagi ilmu pengetahuan dan bisa menerapkan teori yang penulis peroleh pada saat proses perkuliahan yang dipraktikkan dalam dunia usaha yang realistis.

d. Sebagai salah satu syarat untuk menyelesaikan tugas untuk mencapai target Sarjana tepat waktu.

3. Bagi penelitian selanjutnya 
a. Hasil dari penelitian ini diharapkan dapat memberikan kontribusi ilmu dalam hal pengembangan sumber daya manusia serta dapat dijadikan sebagai referensi bagi penelitian selanjutnya dengan topik yang sama.

b. Sebagai referensi bagi peneliti berikutnya khusus yang terkait dengan pengaruhgaya kepemimpinan dan budaya organisasi terhadap kepuasaan kerja karyawan.

\section{LANDASAN TEORI DAN HIPOTESIS}

Menurut Taufik Noor Hidayat (104263213) dalam penelitian(Putra et al., 2016) : Keadaan emosional yang menyenangkan dengan mana karyawan memandang pekerjaan mereka. kepuasaan kerja mencerminkan perasaan seseorang terhadap pekerjaannya. Ini dampak dalam sikap positif karyawan terhadap pekerjaan dan segala sesuatu yang dihadapi dilingkungan kerjanya.

Lima aspek yang terdapat dalam kepuasan kerja, yaitu :

a. Pekerjaan itu sendiri (Work It self), Setiap pekerjaan memerlukan suatu keterampilan tertentu sesuai dengan bidang nya masing-masing. Suka tidaknya suatu pekerjaan serta perasaan seseorang bahwa keahliannya dibutuhkan dalam melakukan pekerjaan tersebut, akan meningkatkan atau mengurangi kepuasan kerja.

b. Atasan (Supervision), atasan yang baik berarti mau menghargai pekerjaan bawahannya. Bagi bawahan, atasan bisa dianggap sebagai figur ayah/ibu/temandan sekaligus atasannya.

c. Teman sekerja (Workers), Merupakan faktor yang berhubungan dengan hubungan antara pegawai dengan atasannya dan dengan pegawai lain, baikyang sama maupun yang berbeda jenis pekerjaannya.

d. Promosi (Promotion), Merupakan faktor yang berhubungan dengan ada tidaknya kesempatan untuk memperoleh peningkatan karier selama bekerja.

e. Gaji/Upah (Pay), Merupakan faktor pemenuhan kebutuhan hidup pegawai yang dianggap layak atau tidak.

Menurut Anwar Prabu dalam penelitian (Putra et al., 2016) ada beberapa indikator yang menyebabkan kepuasan kerja yaitu:

a. Pekerjaan itu sendiri

b. Pengawasan

c. Upah/gaji

d. Promosi/kenaikan jabatan

Tannenbaum, Weschler dan Massarik dalam penelitian (Putra et al., 2016) Kepemimpinan ialah sebuah pengaruh antar pribadi, yang dijalankan pada keadaan tertentu, serta diarahkan lewat proses komunikasi, menuju arah pencapaian satu tujuan tertentu atau lebih. P. Pigors dalam penelitian (Putra et al., 2016) Kepemimpinan ialah proses dorong mendorong lewat keberhasilan sebuah interaksi dari berbagai perbedaan individu, mengontrol daya seseorang dalam mengejar tujuan bersama.

Menurut Djoko santoso Moeljono dalam penelitian (Putra et al., 2016) ada beberapa hal/factor yang menyebabkan seseorang menjadi pemimpin adalah sebagai berikut:

a. Tradisi/warisan; seseorang menjadi pemimpin, karena warisan keturunan, misalnya Raja atau Ratu Inggris dan Belanda.

b. Kekuatan pribadi baik karena alasan fisik maupun karena kecakapannya.

c. Pengangkatan atasan; seseorang menjadi pemimpin, karena diangkat oleh pihak atasannya.

d. Pemilihan; seseorang menjadi pemimpin, karena berdasarkan konsep penerimaan (acceptance thory) anda menjadi pemimpin dan kami akan mentaati intruksi anda. 
Indikator-indikator yang diukur meliputi, yaitu:

a. Keinginan untuk memimpin

Kualitas ini dapat diketahui hanya oleh pengetahuan calon yang baik.Diskusi tentang manajemen, permasalahan-permasalahan yang ada serta minatnya untuk memecahkan masalah, keinginan lebih penting dari pada kecakapan.

b. Kecerdasan

Kualitas ini mungkin ditetapkan dari nilai-nilai ijazah, karya-karya ilmiah pada masamasa silam dan juga melalui psikologi.

c. Kecakapan untuk membuat uraian yang logis

Kualitas ini dapat kita lihat dengan memperhatikan kerja calon, apakah kerjanya baiksecara objektif, rasional serta ideal yang diukur menurut metode ilmiah.

d. Kecakapan untuk berkomunikasi

Penilaian kemampuan calon melalui bahasa. Suatu catatan yang penting mengenai tata bahasa dan ejaan, pemilihan kata-kata, alunan kata-kata, kejelasan bicara, ekspresi serta kemampuan untuk mempertahankan minat selama memberikan penjelasan-penjelasan.

e. Akal budi

Perhatian calon mengenai kebenaran-kebenaran moral, hukum atau kejujuran serta tanggung jawab dalam penggunaan waktu dan perlengkapan kantor,laporan keuangan dan lain-lain.

f. Pengetahuan umum

Penilaian tentang calon apakah mempunyai pengetahuan yang luas baik tentang perusahaan yang ia jalankan, maupun tentang hal-hal di luar perusahaan. Hal ini akan mempengaruhi pendelegasian wewenang.

g. Pengetahuan khusus

Artinya apakah calon mempunyai pengetahuan khusus tentang perusahaan yang akan dipimpinnya, sehingga apabila ia dilimpahi wewenang.

h. Kecakapan menjalin hubungan

Dapat bergaul secara luwes baik terhadap atasan, maupun terhadap bawahan dan rekanrekannya.

Organisasi memiliki arti sebagaimana dinyatakan oleh Robbins dan Judge dalam penelitian (Putra et al., 2016), adalah suatu unit sosial yang terdiri dari dua orang atau lebih, dikoordinasi secara sadar, dan berfungsi dalam suatu dasar yang relatif terus-menerus untuk mencapai satu atau serangkaian tujuan.

Indikator-indicator yang terdapat dari sumber T. Hani Handoko dan Ulber dalam penelitian (Putra et al., 2016), yang diukur meliputi:

a. Formalisasi, mengacu sejauh mana pekerjaan-pekerjaandi dalam organisasi dilakukan untuk mencapai tujuan organisasi.

b. Lingkungan, mengacu sejauh mana keselarasan hubungan terjalin dalam organisasi berpotensi mempengaruhi kinerja organisasi.

c. Fungsi, mengacu sejauh mana keteladanan dalam melakukan pekerjaan, dalam hal ini sebuah tanggung jawab pada pekerjaan yang dilakukan.

d. Sentralisasi, mengacu pada tingkat sejauh mana pengambilan keputusan dikonsentrasikan pada satu titik tunggal dalam organisasi.

Hipotesis

H1 : Gaya kepemimpinan situasional berpengaruh terhadap kepuasan kerja.

H2 : Budaya organisasi berpengaruh terhadap kepuasan kerja. 


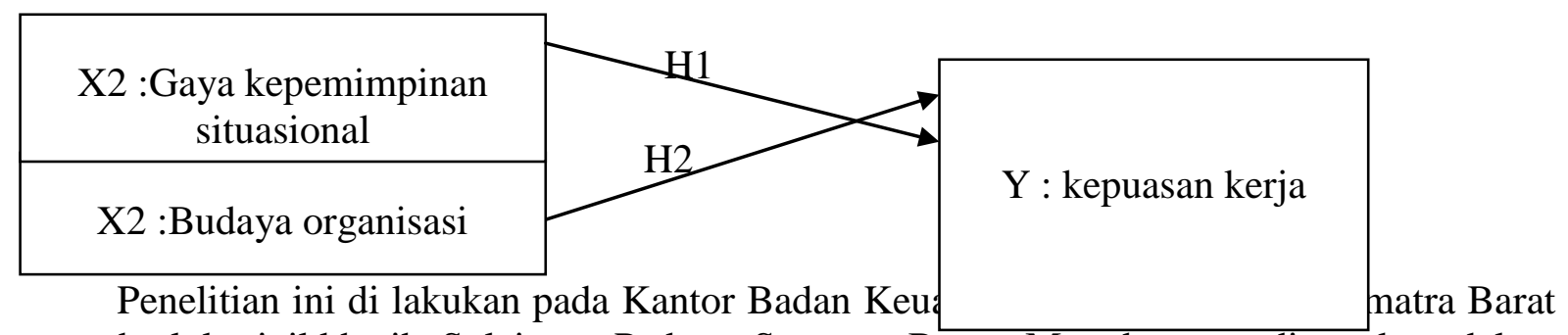

yang berlokasi jl.khatib Sulaiman Padang Sumatra Barat. Metode yang digunakan dalam penelitian ini adalah metode kuntitatif.

Populasi merupakan wilayah generalisasi yang terdiri dari sabjek atau objek yang mempunyai karakteristik dan kuantitas tertentu yang ditetapkan oleh peneliti untuk dipelajari dan kemudian ditarik kesimpulannya menurut (Sugiyono, 2015). Oleh sebab itu dapat ditarik kesimpulannya bahwa populasi tersebut merupakan keseluruhan subjek (orang) ataupun objek (tempat) yang memiliki karakteristik yang berbeda dan bisa diteliti atau bisa diamati.yang menjadi populasi disini adalah semua pegawai yang bekerja di Kantor Badan Keuangan Daerah Provinsi Sumatra Barat.

Sampel adalah Sebagian dari populasi yang diteliti. Yang menjadi sampel disini yaituseluruh pegawai yang bekerja di kantor Badan Keuangan Daerah Provinsi Sumatera Barat, yang mana disitu kuesioner peneliti sebarkan.

Tekniksampel yang di gunakan di sini adalah Sampling Jenuh atau sampel jenuh. Sampel jenuh yaitu suatu teknik dalam penentuan sampel kalau semua anggota populasi itu digunakan sebagai sampel.

Jenis data yang digunakan dalam penelitian ini adalah kuantitatif yaitu data yang berwujud angka-angka. Data ini di peroleh dari pengukuran langsung maupun dari angkaangka yang diperoleh dengan mengubah data kualitatif menjadi data kuantitatif.(Sugiyono, 2015)

Teknik pengumpulan data yang dilakukan dalam penelitian ini adalah Observasi, Kuisioner, interview.

\section{Metode Analisis Data}

\section{Uji Validitas}

Validitas menunjukkan kinerja kuesioner dalam mengukur apa yang diukur. Berbagai macam validitas antara lain sebagai berikut :

Untuk menguji apakah instrumen yang digunakan valid atau tidak dengan korelasi pearson. Cara analisisnya adalah mengkorelasikan antara masing-masing nilai pada nomor pertanyaan dengan nilai total dari nomor pertanyaan tersebut.

Uji validitas dalam penelitian ini digunakan analisis item yaitu mengkorelasikan skor tiap butir dengan skor total yang merupakan jumlah dari tiap skor butir. Jika ada item yang tidak memenuhi syarat, maka item tersebut tidak akan diteliti lebih lanjut. Syarat tersebut menurut Sugiyono, (2010) yang harus dipenuhi yaitu harus memiliki kriteria sebagai berikut:

1. Jika $r>0,30$, maka item-item pertanyaan dari kuesioner adalah valid

2. Jika $r<0,30$, maka item-item pertanyaan dari kuesioner adalah tidak valid

\section{Uji Reabilitas}

Uji Reabilitas adalah suatu uji yang menunjukkan sejauh mana pengukuran ini dapat memberikan hasil yang relativ tidak beda dilakukan pengulangan pengukuran terhadap subjek yang sama. Uji ini hanya dapat dilakukan pada pernyataan yang valid saja.Sakaran, (2006)reliability is the consistency and stability of the measuring instrument, Secara umum, definisi tersebutdapat diartikan bahwa reliabilitas merupakan konsistensi dan stabilitas dari pengukuran instrument. Untuk mengetahui reliabilitas masing-masing variabel penelitian digunakan nilai Croanbach's alpha minimal 0,60 Sakaran, (2006) 
1. Jika $r$ Alpha positif, serta $r>0,06$ maka dimensi tersebut reliable.

2. Jika $r$ Alpha negatif, serta $r<0,06$ maka dimensi tersebut tidak reliable.

Untuk mengetahui hasil validitas dari variable penelitian yaitu kompensasi dan prestasi kerja dilakukan mengunakan SPSS dengan menelaah melalui nilai numeric Corrected ItemTotal Correlation dan koefisien Alpha.

\section{Analisis Statistik Deskriptif (TCR)}

Analisis bermaksud untuk menggambarkan karakteristik masing masing variabel peneliti. Hasil pengolahan data dalam analisis deskriptif kemudian dideskriptifkan dengan tujuan menggunakan proporsi jawaban responden terhadap variabel peneliti.

Menurut (Sugiyono, 2015) total capaian responden merupakan suatu ukuran untuk menghitung masing-masing kategori jawaban dari deskriptif variabel, maka dapat dihitung dengan menggunakan rumusan:

$$
T C R=\frac{\text { Skor tiap item }}{\text { Skor ideal item yang dihitung }} X 100 \%
$$

Keterangan:

TCR $=$ Tingkat Capaian Responden

\section{Uji Asumsi Klasik}

\section{A. Uji Normalitas}

Pengujian normalitas adalah pengujian tentang normalan distribusi data (Sugiyono, 2015) Pengujian normalitas dialakukan untuk mengetahui sebuah data berdistribusi normal atau tidak. Dalam pengujian menggunakan indikator uji Kolmograv-smirnov dengan pedoman sebagai berikut :

1) Jikanilaiprobabilitas $>0,05$ maka Ho diterima

2) Jikanilaiprobabilitas $<0,05$ maka Ho ditolak

3) Pengujian ini dilakukan untuk menentukan apakah Ho diterima atau ditolak dengan melihat nilai probabilitasnya dan membandingkannya dengan alpha (jika nilai probabilitas $>0,05$, maka Ho di terima dan jika nilai probabilitas $<0,05$ maka Ho ditolak)

\section{B. Uji Multikolonearitas}

Multikolinearitas adalah adalah yang berhubungan linear yang sempurna (mendekati sempurna) antara beberapa atau semua variabel bebas (Sugiyono, 2015). Uji multikoneritas bertujuan menguji apakah model regresi yang ditemukan adanya korelasi antara variabel bebas. Model regresi yang baik adalah tidak terjadi korelasi di antara variabel (Hamid \& Mukzam, 2008) Dalam pengujian ini menggunakan indikator sebagai berikut :

1) Tolerance $>0.1$

2) Variance Inflation Factor (VIF) $<10$

ApabilanilaiTolerance $>0.1$ danVariance Inflation Factor $(\mathrm{VIF})<10$, maka tidak terjadi gejala multikonearitas. Sehingga tidak adanya pengaruh anatara variabel yang satu dengan variabel yang lainnya.

\section{Uji heteroskedastisitas}

Uji Heteroskedastisitas yaitu untuk menguji apakah dalam model regresi terjadi ketidak samaan variance dari residual satu pengamatan ke pengamatan yang lain. Jiika Variance dari residual satu pengamatan yang lain tetap maka disebut homoskedastisitas atau tidak terjadi heteroskedastiisitas. Jika pvalue > 0,05 tidak signifikan berarti tidak terjadi heteoskedastisitas artinya model regresi lolos uji heteroskedastisitas (Ghozali,2013).

Oleh karena itu, apabila jika pvalue $>0,05$ maka tidak terjadi gejala heteroskodastisitas. 


\section{Analisis Regresi Berganda}

Regresi menurut Nugroho (2005) bertujuan untuk menguji hubungan pengaruh atas satu variabel dengan yang lain. Variabel yang dipengaruhi disebut variabel terikat atau dependen, sedangkan variabel yang mempengaruhi disebut variabel bebas atau variabel independen. Model persamaan regresi untuk melihat keputusan pembelian konsumen sebagai akibat dari pengaruh persepsi kualitas, persepsi kesesuaian dan Kepuasan kerja adalah sebagai berikut :

$$
\begin{aligned}
& \mathrm{Y}=\alpha+\beta_{1} \mathrm{X} 1+\beta_{2} \mathrm{X} 2 \\
& \text { Dimana : } \\
& \mathrm{Y}=\text { Kepuasan Kerja } \\
& \mathrm{X} 1=\text { Gaya Kepemimpinan Situasional } \\
& \mathrm{X} 2=\text { Budaya Organisasi } \\
& \alpha=\text { KoefisienKonstanta } \\
& \beta 1=\text { Koefisienregresiuntukgaya kepemimpinan situasional } \\
& \beta 2=\text { Koefisienuntuk budaya organisasi }
\end{aligned}
$$

\section{Uji Hipotesis}

\section{A. Uji Simultan (Uji F)}

Digunakan untuk menguji variabel-variabel dependen berpengaruh secara simultan terhadap variabel independen. Adapun pengujian secara signifikan dengan tiingkat signifikansi $\alpha=5 \%$. Jika nilai signifikansi uji F $>5 \%$ maka variabel- variabel independen ditolak berarti model penelitian tidak layak untuk diuji.Namun jika nilai signifikan uji $\mathrm{F}<$ $5 \%$ maka variabel-variabel diterima berarti model penelitian layak untuk diuji.

\section{B. Uji Persial (Uji T)}

Uji T digunakan untuk mengetahui apakah masing-masing variabel bebasnya secara sendiri-sendiri berpengaruh secara signifikan terhadap variabel terikat. Dengan nilai signifikan $5 \%$ dimana thitung $>\mathrm{t}$ tabel maka $\mathrm{H} 0$ diterima menolak Ha yang artinya koefisien korelasi berganda yang dihitung signifikan, dan jika $t$ hiitung $<\mathrm{t}$ tabel maka $\mathrm{H} 0$ ditolak dan menerima Ha yang artinya koefisien korelasi berganda yang dihitung tingkat signifikan dan menunjukkan terdapat pengaruh secara parsial.

\section{Uji Determinasi (R2)}

Pada model linear berganda ini, akan dilihat besarnya kontribusi untuk variabel bebas secara bersama-sama terhadap variabel terikatnya dengan melihat besarnya koefisien determinasi totalnya (R2). Jika (R2) yang diperoleh mendekati 1 (satu) maka dapat dikatakan semakin kuat model tersebut menerangkan hubungan variabel bebas terhadap variabel terikat.Sebaliknya jika (R2) makin mendekati 0 (nol) maka semakin lemah pengaruh variabel-variabel bebas terhadap variabel terikat. 


\section{HASIL DAN PEMBAHASAN}

Pada bagian ini akan dijelaskan mengenai data-data deskriptif yang diperoleh dari responden. responden dalam penelitian ini karyawan Kantor Badan Keuangan Daerah Provinsi Sumatra Barat sejumlah 123 karyawan.

\section{Tabel 4.1}

Karakteristik Responden Menurut Jenis Kelamin,Usia, Pendidikan, dan Golongan

\begin{tabular}{llcc}
\hline Profil & \multicolumn{1}{c}{ Kategori } & $\begin{array}{c}\text { Jumlah } \\
\text { (orang) }\end{array}$ & $\begin{array}{c}\text { Persentase } \\
(\boldsymbol{\%})\end{array}$ \\
\hline Jenis Kelamin & Laki-laki & 52 & 42 \\
Usia & Perempuan & 71 & 58 \\
& $18-25$ thn & 12 & 9 \\
& 26-35 thn & 30 & 24 \\
& 36-46 thn & 52 & 42 \\
Pendidikan & 46 thn & 29 & 24 \\
& SMA/sederajat & 21 & 17 \\
& Diploma & 33 & 26 \\
Golongan & S1 & 31 & 26 \\
& S2 & 38 & 30 \\
& Golongan II & 24 & 19 \\
& Golongan III & 78 & 63 \\
& Golongan IV & 21 & 1 \\
\hline
\end{tabular}

Sumber: data diolah

Berdasarkan tabel 4.1 dapat dilihat bahwa profil responden pertama dibedakan atas jenis kelamin. Berdasarkan kategori ini responden yang paling banyak adalah perempuan yaitu sebanyak 71orang dan sisanya adalah laki-laki yaitu sebanyak 52 orang. Hal ini sesuai dengan tugas yang diberikan oleh Kantor Badan Keuangan Daerah Provinsi Sumatera Barat karena lebih banyak membutuhkan pegawai perempuanyang biasanya perempuan lebih sigap dan cekatan dalam menyelesaikan pekerjaan dan dapat mengerjakan tugas-tugas tanpa mengalami hambatan berarti jika dibandingkan dengan laki-laki.

Profil responden kedua dibedakan atasusia. Berdasarkan kategori ini responden yang paling banyak adalah usia antara 26-35 tahun yaitu sebanyak 30 orang, kemudian usia antara 46 tahun yaitu sebanyak 29 orang, usia antara 36-46 tahun sebanyak 52 orang, Selanjutnya diikuti usia 18-25 tahun yaitu sebanyak 12 orang. Hal ini menjelaskan bahwa karyawan Kantor Badan Keuangan Daerah Provinsi Sumatera Barat lebih banyak pada usia antara 3646 tahun.

Profil responden ketiga dibedakan atas pendidikan. Berdasarkan kategori ini responden yang paling banyak adalah berpendidikan Sarjana (S1) yaitu sebanyak 31 orang, kemudian diikuti dengan pendidikan Diploma yaitu sebanyak 33 orang, selanjutnya pendidikan (S2) sebanyak 38 orang, dan pendidikan SMA/sederajat 21 orang. Hal ini disebabkan pada awal perekrutan karyawan diterimanya pegawai dengan ijazah SMA/sederajat bertujuan untuk membantu tugas-tugas yang dibebankan kepada karyawan yang berijazah sarjana.

Profil responden kempat dibedakan atas golongan. Berdasarkan kategori ini responden yang paling banyak adalah pegawai golongan III yaitu sebanyak 78 orang, kemudian diikuti dengan golongan II sebanyak 24 orang, dan golongan IV sebanyak 21 orang. Pegawai golongan III lebih banyak dari pada golongan II dan golongan IV hal ini disebabkan pada saat penerimaan pegawai sejak pertama kali didirikan oleh pemerintah, salah satu syarat yang diminta adalah sarjana dan sesuai dengan ketentuan yang berlaku pada pegawai negeri sipil dimana penerimaan tingkat sarjana langsung ditempatkan pada golongan III. 
Jadi dapat disimpulkan bahwa responden pada penelitian ini pada umumnya berjenis kelamin Perempuan, berusia antara 36-46 tahun, golongan III bermasa kerja antara 5-10 tahun dengan tingkat pendidikan SMA/sederajat.

\section{Uji Instrumen Data}

Uji validitas adalah suatu langkah pengujian yang dilakukan terhadap isi (content) dari suatu instrumen, dengan tujuan untuk mengukur ketepatan instrumen yang digunakan dalam suatu penelitian (Sugiyono, 2006).

\section{Uji Validitas kuisioner variabel kepuasan kerja (Y)}

Tabel 4.2

Uji validitas kepuasan kerja

\begin{tabular}{cccc}
\hline Kode Item & $\begin{array}{c}\text { Nilai Corrected Item- } \\
\text { Total Correlation }\end{array}$ & $\mathbf{r}_{\text {hitung }}$ & Kesimpulan \\
\hline Item1 & 0,379 & 0,30 & Valid \\
Item2 & 0,370 & 0,30 & Valid \\
Item3 & 0,737 & 0,30 & Valid \\
Item4 & 0,372 & 0,30 & Valid \\
Item5 & 0,737 & 0,30 & Valid \\
Item6 & 0,612 & 0,30 & Valid \\
Item7 & 0,419 & 0,30 & Valid \\
Item8 & 0,321 & 0,30 & Valid \\
Item9 & 0,372 & 0,30 & Valid \\
Item10 & 0,379 & 0,30 & Valid \\
Item11 & 0,370 & 0,30 & Valid \\
Item12 & 0,737 & 0,30 & Valid \\
Item13 & 0,612 & 0,30 & Valid \\
item14 & 0,419 & 0,30 & Valid \\
item15 & 0,737 & 0,30 & Valid \\
item16 & 0,612 & 0,30 & Valid \\
\hline
\end{tabular}

Sumber: data diolah spss

Dari tabel 4.2 diatas dapat disimpulkan bahwa dari 16item pertanyaan yang digunakan dengan nilai Corrected Item-Total Correlation besar dari 0,3. Oleh karena itu dapat disimpulkan seluruh pertanyaan pada tabel diatas dinyatakan valid.

Uji validitas kuisioner gaya kepemimpinan situasional

Tabel 4.3

Uji validitas gaya kepemimpinan situasional

\begin{tabular}{cccc}
\hline Kode Item & $\begin{array}{c}\text { Nilai Corrected Item- } \\
\text { Total Correlation }\end{array}$ & $\mathbf{r}_{\text {hitung }}$ & Kesimpulan \\
\hline Item1 & .376 & 0,30 & Valid \\
Item2 & .357 & 0,30 & Valid \\
Item3 & .786 & 0,30 & Valid \\
Item4 & .365 & 0,30 & Valid \\
Item5 & .786 & 0,30 & Valid \\
Item6 & .590 & 0,30 & Valid \\
Item7 & .411 & 0,30 & Valid \\
Item8 & .332 & 0,30 & Valid \\
Item9 & .365 & 0,30 & Valid \\
Item10 & .376 & 0,30 & Valid \\
Item11 & .357 & 0,30 & Valid \\
Item12 & .786 & 0,30 & Valid \\
Item13 & .590 & 0,30 & Valid \\
\hline
\end{tabular}




\begin{tabular}{llll}
\hline Item14 & .411 & 0,30 & Valid \\
Item15 & .786 & 0,30 & Valid \\
Item16 & .590 & 0,30 & Valid \\
Item17 & .786 & 0,30 & Valid \\
\hline
\end{tabular}

Sumber: data olahan spss

Dari tabel 4.3 diatas dapat disimpulkan bahwa dari 17 item pertanyaan yang digunakan dengan nilai Corrected Item-Total Correlation besar dari 0,3. Oleh karena itu dapat disimpulkan seluruh pertanyaan pada tabel diatas dinyatakan valid.

\section{Uji validitas kuisioner budaya organisasi}

Tabel 4.4

Uji Validitas Budaya Organisasi

\begin{tabular}{cccc}
\hline $\begin{array}{c}\text { Kode } \\
\text { Item }\end{array}$ & $\begin{array}{c}\text { Nilai Corrected Item- } \\
\text { Total Correlation }\end{array}$ & $\mathbf{r}_{\text {hitung }}$ & Keterangan \\
\hline Item1 & .930 & 0,30 & Valid \\
Item2 & .524 & 0,30 & Valid \\
Item3 & .729 & 0,30 & Valid \\
Item4 & .930 & 0,30 & Valid \\
Item5 & .524 & 0,30 & Valid \\
Item6 & .930 & 0,30 & Valid \\
Item7 & .729 & 0,30 & Valid \\
Item8 & .930 & 0,30 & Valid \\
Item9 & .930 & 0,30 & Valid \\
Item10 & .930 & 0,30 & Valid \\
Item11 & .524 & 0,30 & Valid \\
Item12 & .930 & 0,30 & Valid \\
Item13 & .930 & 0,30 & Valid \\
Item14 & .729 & 0,30 & Valid \\
Item15 & .930 & 0,30 & Valid \\
Item16 & .524 & 0,30 & Valid \\
\hline Sumber:data olahan & spss & &
\end{tabular}

Dari tabel 4.4 diatas dapat disimpulkan bahwa dari 16 item pertanyaan yang digunakan dengan nilai Corrected Item-Total Correlation besar dari 0,3. Oleh karena itu dapat disimpulkan seluruh pertanyaan pada tabel diatas dinyatakan valid.

\section{Uji Reabilitas}

Tabel 4.5

Hasil uji reabilitas

\begin{tabular}{lccc}
\hline Variabel Penelitian & $\begin{array}{c}\text { Nilai Cronbach's } \\
\text { Alpha }\end{array}$ & $\begin{array}{c}\text { Jumlah } \\
\text { item }\end{array}$ & Keterangan \\
\hline Kepuasan Kerja (Y) & 0,876 & 16 & Reliabel \\
Gaya Kepemimpinan & 0,891 & 17 & Reliabel \\
Situasional (X1) & 0,967 & 16 & Reliabel \\
$\begin{array}{l}\text { Budaya } \\
\text { Organisasi(x2) }\end{array}$ & & & \\
\hline
\end{tabular}

Sumber: Data Olahan

Untuk uji reliabilitas terlihat bahwa variabel kepuasan kerja memiliki angka Cronbach Alpha 0,876, variabel gaya kepemimpinan situasional memiliki angka Cronbach Alpha 0,891, begitu juga untuk variabel budaya organisasi memiliki angka Cronbach Alpha 0,967, dimana semuanya berada diatas 0,50 . 
Uji Asumsi Klasik

A. Uji Normalitas

Tabel 4.6

Hasil Uji Normalitas

\begin{tabular}{ccc}
\hline & $\begin{array}{c}\text { Standardized } \\
\text { Residual }\end{array}$ & Keterangan \\
\hline Kolmogorov-Smirnov Z & 0,959 & Distribusi Normal \\
Asymp. Sig (2-tailed) & 0,317 & \\
\hline
\end{tabular}

Sumber : data diolah spss

Dari Tabel 4.6 Pada tabel diatas dengan uji One-Sample Kolmogorov-Smirnov Test hasil dari uji tersebut menunjukan asymp. Sig Standardized residual adalah 0,317. Hal ini dapat disimpulkan bahwa nilai signifikannya lebih besar dari alpha 0,05 dengan demikian menunjukan data terdistribusi secara normal.

\section{B. Uji multikoloneritas}

Tabel 4.7

Hasil Uji Multikoliniearitas

\begin{tabular}{ccccc}
\hline No & Variabel & Tolerance & VIF & Keterangan \\
\hline 1 & $\begin{array}{c}\text { Gaya } \\
\text { kepemimpinan } \\
\text { situasional (X1) }\end{array}$ & 0,994 & 1,006 & $\begin{array}{c}\text { Tidak terjadi } \\
\text { Multikoliniearitas }\end{array}$ \\
$\begin{array}{c}\text { Budaya Organisasi } \\
(\mathrm{X} 2)\end{array}$ & 0,994 & 1,006 & $\begin{array}{c}\text { Tidak terjadi } \\
\text { Multikoliniearitas }\end{array}$ \\
\hline
\end{tabular}

Sumber :(Lampiran SPSS)

Berdasarkan Tabel 4.7 hasil pengujian multikolinearitas yang telah dilakukan terindentifikasi bahwa masing-masing variabel independen yang digunakan memiliki nilai tolerance diatas 0,10 sedangkan nilai Variance Influence Faktor (VIF) yang dimiliki masing- masing variabel independen berada dibawah 10, sehingga dapat dikatakan bahwa seluruh variabel independen yang digunakan terbebas dari gejala multikolinearitas, sehingga pengolahan data lebih lanjut bisa dilakukan.

\section{C.Uji heteroskedastisitas}

Tabel 4.8

Hasil Uji Heterokedastisitas

\begin{tabular}{ccccc}
\hline No & Variabel & Alpha & Sig & Keterangan \\
\hline & Gaya & 0,05 & 0,459 & Tidak terjadi \\
1 & $\begin{array}{c}\text { Kepemimpinan } \\
\text { Situasional (X1) }\end{array}$ & & & Heterokedastisitas \\
& $\begin{array}{c}\text { Budaya Organisasi } \\
(\mathrm{X} 2)\end{array}$ & 0,05 & 0,833 & $\begin{array}{c}\text { Tidak terjadi } \\
\text { Heterokedastisitas }\end{array}$ \\
\hline
\end{tabular}

Data SPSS, Lampiran 5

BerdasarkanUji heteroskedastisitas dapat dilihat pada tabel 4.12 diatas menunjukan bahwa nila Asymp.Sig pada semua variabel bebas (independen) menunjukan lebih besar dari 0,05 sehingga dapat disimpulkan bahwa semua variabel independen pada penelitian ini tidak terjadi heteroskedastisitas. 
Tabel 4.9

Hasil Analisa Regresi Linear Berganda

\begin{tabular}{|c|c|c|c|c|c|}
\hline \multirow[b]{3}{*}{ Model } & \multicolumn{3}{|c|}{ Coefficients $^{\mathrm{a}}$} & \multirow[b]{3}{*}{$\mathrm{T}$} & \multirow[b]{3}{*}{ Sig. } \\
\hline & \multicolumn{2}{|c|}{$\begin{array}{l}\text { Unstandardized } \\
\text { Coefficients }\end{array}$} & \multirow{2}{*}{$\begin{array}{c}\text { Standardized } \\
\text { Coefficients } \\
\text { Beta }\end{array}$} & & \\
\hline & $\mathrm{B}$ & Std. Error & & & \\
\hline 1 (Constant) & 0,563 & 1,497 & & 0,376 & 0,707 \\
\hline $\begin{array}{l}\text { Gaya Kepemimpinan } \\
\text { Situasional }\end{array}$ & 0,935 & 0,020 & 0,970 & 47,296 & 0,000 \\
\hline Budaya Organisasi & 0,037 & 0,018 & 0,042 & 2,058 & 0,042 \\
\hline
\end{tabular}

Sumber:data diolah spss

\section{Model Analisis Berganda}

$\mathrm{Y}=\mathrm{a}+\mathrm{b} 1 \cdot \mathrm{XI}=\mathrm{b2} \cdot \mathrm{X2}=\mathrm{e}$

$Y=1,497+0,020 \times 1+0,018 \times 2$

Dimana:

Y =Kepuasan kerja

A $=$ Konstanta

$\mathrm{B}=$ Koefisien variabel

$\mathrm{X} 1$ =Gaya Kepemimpinan Situasional

$\mathrm{X} 2$ =Budaya Organisasi

$\mathrm{E}=$ Standar Eror

Interprestasi dari linear berganda sebagai berikut:

a. Berdasarkan tabel 4.13 diatas dapat diketahui bahwa ada tidak adanya variaber $\mathrm{Y}$ tidak mempengaruhi variabel lain karena nilai konstanta adalah 1,497 yang menunjukan tanpa variabel bebas.

b. koefisien Regresi X1=0,020 menyatakan bahwa setiap peningkatan variabel gaya kepemimpinan situasional akan meningkatkan kepuasan kerja sebesar0,020 dan menganggap variabel lainnya variabel konstanta.

c. 0,018 menyatakan bahwa budaya organisasi akan meningkatkan kepuasan kerja sebesar 0,018 dengan menganggap variabel lainya variabel konstanta.

\section{Pengujian Hipotesis}

Tabel 4.10

Hasil Uji Simultan (Uji F)

\begin{tabular}{ccccccc}
\hline & & \multicolumn{3}{c}{ ANOVA $^{\mathbf{b}}$} & & \\
& \multirow{2}{*}{ Model } & Sum of & Sf & Mean Square & F & Sig. \\
\hline 1 & Regression & 9209,806 & 2 & 4604,903 & 1,1353 & $0,000^{\text {a }}$ \\
& Residual & 486,844 & 120 & 4,057 & & \\
& Total & 9696,650 & 122 & & & \\
\hline
\end{tabular}

Sumber: olahan data

Berdasarkan hasil pengolahan data pada tabel terlihat bahwa nilai $\mathrm{F}$ sebesar 1,1353 dan nilai sigifikan $\mathrm{F}$ untuk variabel gaya kepemimpinan situasional dan budaya organisasi sebesar 0,000. Karena Karena nilai Sig F $=0,000<0,05$, maka dapat diartikan bahwa variabel gaya kepemimpinan situasional, budaya organisasi dan kepuasan kerja secara bersama-sama dapat menjelaskan nilai variabel terikat. Apabila $\mathrm{f}_{\text {hitung }}<\mathrm{F}_{\text {tabel, }}$ maka Ho diterima dan Ha ditolak. 
Tabel 4.16

Hasil Uji Parsial (Uji T)

Coefficients $^{\mathbf{a}}$

\begin{tabular}{lccccc}
\hline & \multicolumn{2}{c}{$\begin{array}{l}\text { Unstandardized } \\
\text { Coefficients }\end{array}$} & $\begin{array}{c}\text { Standardized } \\
\text { Coefficients }\end{array}$ & & \\
Model & B & Std. Error & Beta & T & Sig. \\
\hline 1 (Constant) & 0,563 & 1,497 & & 0,376 & 0,707 \\
$\quad \begin{array}{l}\text { Gaya Kepemimpinan } \\
\text { Situasional }\end{array}$ & 0,935 & 0,020 & 0,970 & 47,296 & 0,000 \\
Budaya Organisasi & 0,037 & 0,018 & 0,042 & 2,058 & 0,042 \\
\hline
\end{tabular}

Hasil uji T diatas dapat disimpulkan bahwa variabel gaya kepemimpinan situasional (X1) diperoleh nilai t sebesar 47,296 terhadap kepuasan kerja dengan Sig 0,000 dibawah 0,05, apabila $t_{\text {hitung }}<t_{\text {tabel }}$ maka Ho diterima dan Ha ditolak. Dengan demikian H1 diterima, yang artinya terdapat pengaruh positif dan signifikan gaya kepemimpinan situasional secara parsial terhadap kepuasan kerja (Y).

Hasil uji $\mathrm{T}$ variabel budaya organisasi (X2) pada tabel 4.15 diatas diperoleh nilai $\mathrm{t}$ sebesar 2,058 terhadap kepuasan kerja dengan Sig 0,042 dibawah 0,05, apabila $t_{\text {hitung }}<t_{\text {tabel }}$ maka Ho diterima dan Ha ditolak. Dengan demikian $\mathrm{H} 2$ diterima, yang artinya terdapat pengaruh positif budaya organisasi terhadap kepuasan kerja.

Tabel 4.17

Hasil Uji Determinasi (UJI R2)

Model Summary ${ }^{b}$

\begin{tabular}{lcccc}
\hline Model & R & R Square & $\begin{array}{c}\text { Adjusted R } \\
\text { Square }\end{array}$ & $\begin{array}{c}\text { Std. Error of } \\
\text { the Estimate }\end{array}$ \\
1 & $0,975^{\mathrm{a}}$ & 0,950 & 0,949 & 2,014 \\
\hline
\end{tabular}

Sumber: Olahan Data

Berdasar hasil uji koefisien determinasi diatas dapat dilihat bahwa nilai Adjusted R2 yang diperoleh hanya sebesar 0,949. Hal ini menunjukan bahwa besarnya konstribusi gaya kepemimpinan situasional dan budaya organisasi terhadap kepuasan kerja sebesar0,949. Dan sisanya dipengaruhi oleh variabel lain yang tidak termasuk dalam penelitian ini.

\section{PEMBAHASAN}

\section{Pengaruh gaya kepemimpinan situasional terhadap Kepuasan kerja}

Berdasarkan hasil pengujian hipotesis pertama, ditemukan bahwa variabel gaya kepemimpinan berpengaruh positif dan signifikan terhadap kepuasan kerja Badan Keuangan Daerah Provinsi Sumatera Barat. Besaran koefisien regresi variabel gaya kepemimpinan situasional adalah 47,296 dan signifikansinya 0,000 yang kecil dari $\alpha=0,05$.

Hal ini dapat diartikan bahwa variabel gaya kepemimpinan situasional berpengaruh positif dan signifikan terhadap kepuasan kerja.Dengan demikian, hipotesis pertama $\left(\mathrm{H}_{1}\right)$ dalam penelitian ini yang menyatakan bahwa gaya kepemimpinan situasional berpengaruh positif dan signifikan terhadap kepuasan kerja karyawan Badan Keuagan Daerah Provinsi Sumatera Barat, dinyatakan diterima.

\section{Pengaruh budaya organisasi Terhadap Kepuasan kerja}

Berdasarkan hasil pengujian hipotesis kedua, ditemukan bahwa variabel budaya organisasi berpengaruh positif dan signifikan terhadap kepuasan kerja Badan Keuangan 
Daerah Provinsi Sumatera Barat.Besaran koefisien regresi variabel budaya organisasi adalah 2,058dan signifikan sebesar 0,042. Nilai signifikan tersebut kecil dari $\alpha=0,05$. Hal ini dapat diartikan bahwa variabel budaya organisasi berpengaruh positif terhadap Kepuasan kerja.Dengan demikian, hipotesis kedua $\left(\mathrm{H}_{2}\right)$ dalam penelitian ini yang menyatakan bahwa budaya organisasi berpengaruh positif dan signifikan terhadap kepuasan kerja pada Badan Keuangan Daerah Provinsi Sumatera Barat, dinyatakan diterima.

\section{SIMPULAN}

Dari hasil pengujian hipotesis yang telah dilakukan mengenai analisis Pengaruh gaya kepemimpinan situasional dan budaya organisasi terhadap kepuasan kerja maka dapat ditarik kesimpulan sebagai berikut:

1. Variabel gaya kepemimpinan situasional tidak berpengaruh positif dan signifikan terhadap kepuasan kerja.

2. Variabel budaya organisasi tidak berpengaruh positif dan signifikan terhadap kepuasan kerja.

\section{UCAPAN TERIMAKASIH}

Selesainya penelitian ini penulis banyak mendapatkan bantuan dan dorongan baik secara moril, maupun spritual, oleh karena itu penulis ingin menyampaikan rasa trimakasih yang sebesar besarnya kepada : Bapak Febryandhie Ananda, SE.,M.Si selaku ketua STIE "KBP" Padang, Ibu lidya martha,SE,MM selaku wakil ketua STIE “KBP” padang, Ibu Febsri Susanti, SEI, MM selaku ketua program studi Manajemen, Bapak henryanto Abaharis, SE,M.Si selaku pembimbing yang telah bersedia meluangkan waktu membimbing dalam penulisan penelitian ini, Ibu Maria magdalena, SPd,M.M selaku penasehat akademik program program studi manajemen dan kepada semua pihak yang telah banyak membantu penulis yang tidak bisa penulis sebutkan satu persatu.

\section{DAFTAR PUSTAKA}

Hamid, D., \& Mukzam, M. D. (2008). Pengaruh Motivasi Kerja Dan Kemampuan Kerja Terhadap Kinerja Karyawan.

Hamid, D., \& Ruhana, I. (2008.). Pengaruh Gaya Kepemimpinan Situasional Dan Budaya Organisasi Terhadap Kepuasan Kerja

Marlius, D. RD Putra. (2018). Strategi Pengembangan Sulam Bayang. Jurnal Benefita: Ekonomi Pembangunan Manajemen Bisnis Dan Akuntansi. Volume 3. No. 2. Hal. 204-218. http://doi.org/10.22216/jbe.v3i2.3494

Mayliza, R. (2019). Pengaruh Gaya Kepemimpinan Dan Disiplin Kerja Terhadap Kinerja Karyawan Dengan Motivasi Kerja Sebagai Variabel Intervening Pada PT. Semen Padang. https://doi.org/10.17605/OSF.IO/FYPQ9.

Mayliza, R. (2019). Pengaruh Konflik Dan Kejenuhan Terhadap Kepuasan Kerja Karyawan PT. PLN (Persero) Sektor Pembangkitan Dan Pengendalian Pembangkitan Ombilin. https://doi.org/10.17605/OSF.IO/DQZ3K

Mayliza, R. (2019). Kontribusi Sistem Penghargaan Dan Lingkungan Kerja Terhadap Efektifitas Kerja Pegawai Pada Kantor Dinas Pendidikan Kota Padang. https://doi.org/10.17605/OSF.IO/VWZH3

Mayliza, R. (2019). Pengaruh Gaya Kepemimpinan Dan Disiplin Kerja Terhadap Kinerja Pegawai, Dengan Motivasi Kerja Sebagai Variabel Intervening (Studi Pada Dinas Pendidikan Kabupaten Tanah Datar). https://doi.org/10.17605/OSF.IO/JGPDN

Nardo, R. Evanita, Syahrizal, S. (2018). Pengaruh Kepemimpinan Transformasional, Dan Lingkungan Kerja Non Fisik Terhadap Perilaku Inovatif. JEBI (Jurnal Ekonomi dan Bisnis Islam) 3 (2), 209-215 
Nardo, R. Evanita, Syahrizal, S. (2019). The Effect of Transformational Leadership and Non Physical Work Environment on Innovative Behavior with Work Motivation as a Mediation For Employees of Tour And Travel Companies In West Sumatera. 2nd Padang International Conference on Education, Economics, Business and Accounting (PICEEBA-2 2018)

Pottale, B. (2016). Pengaruh Proses Rekrutmen dan Seleksi Terhadap Kinerja Karyawan Pada PT. Bank SulutGo The Influence Of The Recruitmen Process For And Selection Of The Performance Of Employess At PT. Bank SulutGo. Berkala Ilmiah Efisien, 16(4), 453-464.

Putra, RY. Marlius, D. (2019). Pengaruh Pendidikan, Pengalaman Kerja dan Etos Kerja Terhadap Kinerja Pegawai Di KPN Batur. Academic Conference For Management 2.

Putra, D., Wilajaya, T., Akuntansi, A., \& Harapan, P. (2016). Pengaruh Gaya Kepemimpinan Dan Budaya Organisasi Terhadap Kepuasan Kerja Karyawan Humas Badan Pengusahaan Batam.

Ridho, M., \& Susanti, F. (2019). Pengaruh Stres Kerja Dan Motivasi Kerja Terhadap Kepuasan Kerja Pada Karyawan Bank Mandiri Syariah Cabang Padang. https://doi.org/10.31227/osf.io/pa2cg

Lubis, A. Y. O., \& Susanti, F. (2019). Pengaruh Gaya Kepemimpinan Dan Kompensasi Terhadap Prestasi Kerja Karyawan (Studi pada PT Japfa Comfeed Indonesia (JCI) Tbk Devisi Fam 1. https://doi.org/10.31227/osf.io/7tbrg

Aldi, Y., \& Susanti, F. (2019). Pengaruh Stress Kerja Dan Motivasi Kerja Terhadap Prestasi Kerja Karyawan Pada PT. Frisian Flag Indonesia Wilayah Padang. https://doi.org/10.31227/osf.io/et4rn

Widodo, B. H., \& Susanti, F. (2019). Pengaruh Human Relation (Hubungan Antar Manusia), Lingkungan kerja Terhadap Etos Kerja karyawan (Studi Kasus Pada PT. Pelindo Teluk Bayur Padang ). https://doi.org/10.31227/osf.io/dxm8a

Sugiyono. (2015). Statistik Nonparametris (Bayu Rahma). Bandung.

Susriyanti, S. Nardo, R. (2019). Pengaruh Fungsi Komunikasi Dan Kepuasan Kerja Karyawan Terhadap Pemberian Pelayanan Nasabah PT. BPR LPN Talawi Sakato. Jurnal Administrasi Sosial dan Humaniora 3 (2), 97-111

Wirda, F. (2012). Pengaruh Gaya Kepemimpinan Situasional Dan Motivasi Kerja Terhadap Kepuasan Kerja Karyawan Politeknik Negeri Padang,4(1), 24-33.

Yudistira, D. S., \& Susanti, F. (2019). Pengaruh Motivasi Kerja Dan Budaya Kerja Terhadap Kinerja Karyawan Dinas Pemberdayaan Masyarakat Dan Desa, Pengendalian Penduduk Dan Keluarga Berencana Kabupaten Pesisir Selatan. https://doi.org/10.31227/osf.io/jk54m 